\title{
Uspešnost Slovenije pri črpanju kohezijskih sredstev EU v obdobju 2004-2006
}

UDK: $35.072 .8(497.4): 336 E U$

\author{
Aleksander Aristovnik \\ Univerza v Ljubljani, Fakulteta za upravo \\ aleksander.aristovnik@fu.uni-lj.si
}

Neja Lah

Služba vlade RS za lokalno samoupravo in regionalno politiko

neja.lah@gov.si

\begin{abstract}
IZVLEČEK
Članstvo v Evropski uniji (EU) ponuja Sloveniji edinstveno priložnost zagona gospodarskega razvoja in procesa realne konvergence, ki je v prvem obdobju članstva ni v celoti izkoristila. Čeprav je Slovenija pri črpanju sredstev EU ena najuspešnejših novih držav članic, je do konca leta 2006, kljub statusu neto prejemnice, izkoristila le okoli polovice dodeljenih sredstev za obdobje 2004-2006. Glavni razlog za to lahko iščemo predvsem v slabi izkoriščenosti kohezijskih sredstev, ki bodo $v$ prihodnosti predstavljali pretežni del prilivov iz proračuna EU. Če želi Slovenija izkoristiti znatna razpoložljiva kohezijska sredstva EU, bo morala v prihodnosti nujno povečati predvsem administrativno sposobnost črpanja teh sredstev. Za uspešnejše črpanje evropskih sredstev bo tako, poleg dodatnega prestrukturiranja proračunskih izdatkov in uporabe dobrih praks iz tujine, treba zagotoviti tudi višjo stopnjo strokovnosti in učinkovitosti oz. uspešnosti slovenske državne uprave.
\end{abstract}

Ključne besede: EU, strukturni skladi, Kohezijski sklad, administrativna usposobljenost, državna uprava, Slovenija

\section{Uvod}

Slovenija je $v$ zadnjih letih dosegla vrsto zastavljenih strateških ciljev, med katerimi izstopata predvsem vstop v Evropsko unijo (EU) leta 2004 in kasneje tudi $\vee$ Gospodarsko in denarno unijo (GDU) leta 2007. Naslednji strateški cilj Slovenije pomeni doseči oziroma preseči povprečno raven ekonomske razvitosti EU do leta 2013, ob upoštevanju načel trajnostnega razvoja in dolgoročnega 
Aleksander Aristovnik, Neja Lah

Uspešnost Slovenije pri črpanju kohezijskih

sredstev EU v obdobju 2004-2006

ohranjanja ekonomskih, socialnih in okoljskih ravnotežij. Po zadnjih podatkih Slovenija dosega 88-odstotno raven razvitosti EU-27 oziroma 80-odstotno raven razvitosti držav članic GDU (I. 2006). Pri doseganju zastavljenega strateškega cilja pa bodo eno ključnih vlog imela tudi znatna razpoložljiva kohezijska sredstva EU, ki bodo morala biti v tekoči finančni perspektivi 20072013 uporabljena veliko bolj uspešno in učinkovito kot v obdobju 2004-2006.

Temeljni namen članka je predstaviti dosedanjo (ne)uspešnost Slovenije pri črpanju kohezijskih sredstev EU in opozoriti na ovire, ki onemogočajo višjo stopnjo tovrstne uspešnosti. Članek najprej predstavi predvideni in dejanski neto finančni priliv sredstev EU $\vee$ Slovenijo $\vee$ obdobju 2004-2006. $\vee$ nadaljevanju članek posebej predstavi sistem črpanja kohezijskih sredstev EU in institucije, vključene $v$ ta sistem črpanja na ravni Republike Slovenije. $V$ četrtem delu se članek osredotoči na probleme pri črpanju kohezijskih sredstev EU in $v$ petem delu osvetli rešitve za izboljšanje uspešnosti črpanja razpoložljivih evropskih sredstev $\vee$ tekoči finančni perspektivi. Na koncu so povzete tudi glavne ugotovitve članka.

\section{Slovenija - neto prejemnica EU sredstev v obdobju 2004-2006}

\subsection{Neto finančni položaj Slovenije v letu 2004}

Slovenija je $\vee$ slabem prvem letu članstva $\vee$ EU predvidela finančne prejemke $\vee$ znesku 335,5 milijona evrov (1,3 odstotka BDP), ki naj bi za okoli 80 odstotkov presegli njena predvidena finančna izplačila $v$ skupno evropsko blagajno. Pričakovano so bila predvidevanja glede na slovensko neizkušenost pri koriščenju finančnih sredstev EU previsoka, kar kažejo tudi dejanski finančni rezultati. Tako je v letu 2004 Slovenija prejela le okoli 55 odstotkov predvidenih evropskih prejemkov (182,8 milijona evrov), predvsem na račun popolne neizkoriščenosti razpoložljivih sredstev iz naslova kohezijske ${ }^{\boldsymbol{1}}$ in notranje politike. Veliko bolje se je Slovenija odrezala pri izkoriščanju sredstev iz predpristopnih pomoči (44,7 milijona evrov) in skupne kmetijske politike (SKP) (23,0 milijona

$1 \mathrm{~V}$ članku bo pojem kohezijska politika vključeval tako instrumente strukturnih skladov kot tudi Kohezijskega sklada. 


\section{Aleksander Aristovnik, Neja Lah \\ Uspešnost Slovenije pri črpanju kohezijskih sredstev EU v obdobju 2004-2006}

evrov), kjer je bila dosežena 50-odstotna stopnja izkoriščenosti sredstev EU. Praktično so finančne prilive evropskih sredstev v Slovenijo leta 2004 reševala pavšalna plačila (112,7 milijona evrov), ki so predvideni tok presegla za okoli 10 odstotkov ter pomenila več kot 60 odstotkov celotnega finančnega priliva evropskih sredstev (glej razpredelnico 1).

$\mathrm{Na}$ drugi strani so se pričakovanja glede vplačanih sredstev Slovenije $\vee$ proračun EU (pričakovano) uresničila več kot 90 odstotno (169,4 milijona evrov). Ni presenetljivo, da je to Slovenijo, skupaj z relativno nizko stopnjo uresničitve predvidenih finančnih prilivov, privedlo na rob položaja neto plačnice $v$ proračun EU. Iz predvidenih 147,3 milijone evrov neto priliva je Slovenija prejela le 13,4 milijona evrov (0,05 odstotka BDP) neto finančnih sredstev EU, tj. slabih 10 odstotkov načrtovane neto finančnega položaja Slovenije nasproti EU. Še več, če upoštevamo samo obdobje od začetka maja do konca decembra 2004, je bila Slovenija celo v negativnem neto finančnem položaju v znesku 14,6 milijona evrov. Skrb zbujajoč podatek kaže predvsem že omenjena neizkoriščenost sredstev EU iz kohezijske in notranje politike, ki pa je bila $\vee$ prejšnjih programskih obdobjih značilna tudi za nekatere stare države članice (npr. Portugalska in Irska) ter je prisotna $v$ prvem koledarskem letu članstva tudi pri nekaterih novih državah članicah EU (npr. na Poljskem).

\subsection{Neto finančni položaj Slovenije v letu 2005}

Rebalans proračuna Slovenije za leto 2005 je predvideval, da naj bi Slovenija do konca leta iz bruseljske blagajne prejela 483,6 milijona evrov, skupna vplačila $v$ proračun EU pa naj ne bi presegla 305 milijonov evrov. To pomeni, da naj bi bila Slovenija v letu 2005 neto prejemnica sredstev EU predvidoma $v$ znesku 178,6 milijona evrov (0,65 odstotka BDP). Že same izkušnje slovenskega črpanja sredstev EU v letu 2004 pa so pokazale nerealnost ocene in premajhno usmerjenost nacionalnega proračuna $v$ večjo izkoriščenost razpoložljivih sredstev EU. Tudi rezultati v letu 2005 so pokazali relativno visoko stopnjo neuspešnosti pri porabi razvojih sredstev, saj je Slovenija $v$ tem letu dosegla le okoli 63 odstotkov načrtovanih prilivov, predvsem na račun nizke izkoriščenosti sredstev za potrebe notranje politike (izkoristila le 10 odstotkov načrtovanih prilivov) in kohezijske politike (izkoristila le 28 odstotkov načrtovanih prilivov) (glej razpredelnico 1). 


\section{Aleksander Aristovnik, Neja Lah \\ Uspešnost Slovenije pri črpanju kohezijskih \\ sredstev EU v obdobju 2004-2006}

V luči omenjenih težav je Vlada RS marca 2005 sprejela 34 sklepov, ki naj bi pospešili črpanje sredstev strukturnih in Kohezijskega sklada. Hkrati je bilo izjemno slabo črpanje sredstev $v$ preteklosti eden temeljnih vzrokov za takratni rebalans proračuna Slovenije, ki ga je Državni zbor RS sprejel junija 2005. ${ }^{2}$ Po prerazporeditvi sredstev $\vee$ proračunu se je pričakovala in tudi uresničila nekoliko višja stopnja izkoriščenosti sredstev EU. Tako je Slovenija v letu 2005 dosegla 17,1 milijona evrov (0,06 odstotka BDP) presežka prejetih nad vplačanimi sredstvu v proračun EU, kar je še vedno pomenilo le okoli desetino predvidenega obsega.

\subsection{Neto finančni položaj Slovenije v letu 2006}

Leto 2006 je bilo z vidika črpanja sredstev EU za Slovenijo prelomno, saj je dosegla relativno visoko stopnjo izkoriščenosti razpoložljivih sredstev EU. Kljub temu, da je Slovenija to leto prejela le 78 odstotkov predvidenih prilivov od EU, je dosegla neto priliv $v$ višini 60,5 milijona evrov (0,20 odstotka BDP) oziroma 44 odstotkov predvidenega obsega. Izrazito izboljšanje glede na pretekla leta je zaznati na področju kohezijske politike (Slovenija je uresničila 81 odstotkov predvidenih sredstev) ${ }^{3}$, medtem ko je še vedno problematično črpanje sredstev iz schengenskega vira, saj je država počrpala le 27 odstotkov predvidenih sredstev. Podobno kot pretekla leta, je bila Slovenija najuspešnejša pri črpanju sredstev SKP (prejela 96 odstotkov predvidenih sredstev) in pridobivanju pavšalnih povračil (prejela 90 odstotkov predvidenih sredstev).

Kljub na prvi pogled relativno slabemu izkoristku Slovenija še zdaleč ni neuspešna porabnica (strukturnih) sredstev EU, sploh če jo primerjamo $s$ preostalimi novimi državami članicami EU. Tako slika 1 prikazuje mednarodno primerjavo črpanja razpoložljivih strukturnih sredstev EU v obdobju 2004-2006 $\checkmark$ novih državah članicah.

2 Rebalans proračuna RS za leto 2005. Ljubljana: Ministrstvo za finance, junij 2005.

3 Leta 2006 je Slovenija iz proračuna Skupnosti prejela 85,5 mio EUR iz sredstev strukturne politike, tako da je državni proračun $v$ odnosu do proračuna EU realiziral do sedaj najvišji neto proračunski presežek. $V$ istem letu je Slovenija tudi izpolnila pravilo " $N+2$ " pri vseh skladih v okviru Enotnega programskega dokumenta (EPD) 2004-2006. 
Aleksander Aristovnik, Neja Lah

Uspešnost Slovenije pri črpanju kohezijskih sredstev EU v obdobju 2004-2006

Razpredelnica 1: Predvideni in dejanski neto finančni položaj Slovenije v EU v obdobju 2004-2006 (v milijonih evrov, tekoče cene)

\begin{tabular}{|l|c|c|c|c|c|c|}
\hline \multirow{2}{*}{ v mio EUR } & \multicolumn{2}{|c|}{2004} & \multicolumn{2}{c|}{2005} & \multicolumn{2}{c|}{2006} \\
\cline { 2 - 7 } & Predvideno & Dejansko & Predvideno* & Dejansko & Predvideno & Dejansko \\
\hline Prejeta sredstva iz EU & 335,5 & 182,8 & 483,6 & 302,5 & 449,4 & 348,4 \\
\hline Predpristopna sredstva & 88,0 & 44,7 & 58,0 & 47,2 & 36,7 & 25,9 \\
SKP & 46,7 & 23,0 & 113,9 & 111,8 & 142,3 & 136,0 \\
Strukturna politika & 32,1 & 0,0 & 111,8 & 35,9 & 104,7 & 85,5 \\
Kohezijska politika & 27,5 & 0,0 & 42,6 & 7,5 & 27,1 & 20,9 \\
Notranja politika & 38,4 & 0,0 & 65,1 & 6,3 & 76,8 & 20,4 \\
Pavšalna povračila & 102,2 & 112,7 & 92,6 & 91,0 & 62,2 & 55,9 \\
\hline Plačila sredstev v EU & 187,8 & 169,4 & 305,0 & 285,4 & 315,1 & 287,9 \\
\hline Tradicionalni lastni viri & 15,0 & 12,5 & 28,8 & 28,0 & 31,7 & 35,5 \\
Popravek v korist VB & 14,6 & 16,3 & 25,9 & 23,0 & 25,9 & 23,4 \\
\hline SkV vir & 27,5 & 25,0 & 44,2 & 43,8 & 47,2 & 47,6 \\
\hline v \% BDP & 147,3 & 13,4 & 178,6 & 17,1 & 134,4 & 60,5 \\
\hline
\end{tabular}

Opomba:

* stanje po rebalansu proračuna junija 2005.

** gre za predvidevanja Evropske komisije (EK) na osnovi pogajanj decembra 2002.

Vir: Bilten javnih financ 2004, 2005, 2006 in 2007; lastni izračuni. 
Aleksander Aristovnik, Neja Lah

Uspešnost Slovenije pri črpanju kohezijskih

sredstev EU v obdobju 2004-2006

Slika 1: Deleži plačil glede na dodeljena sredstva strukturnih skladov in pobude EQUAL za države nove članice EU-10 v obdobju 2004-2006 (v \%)

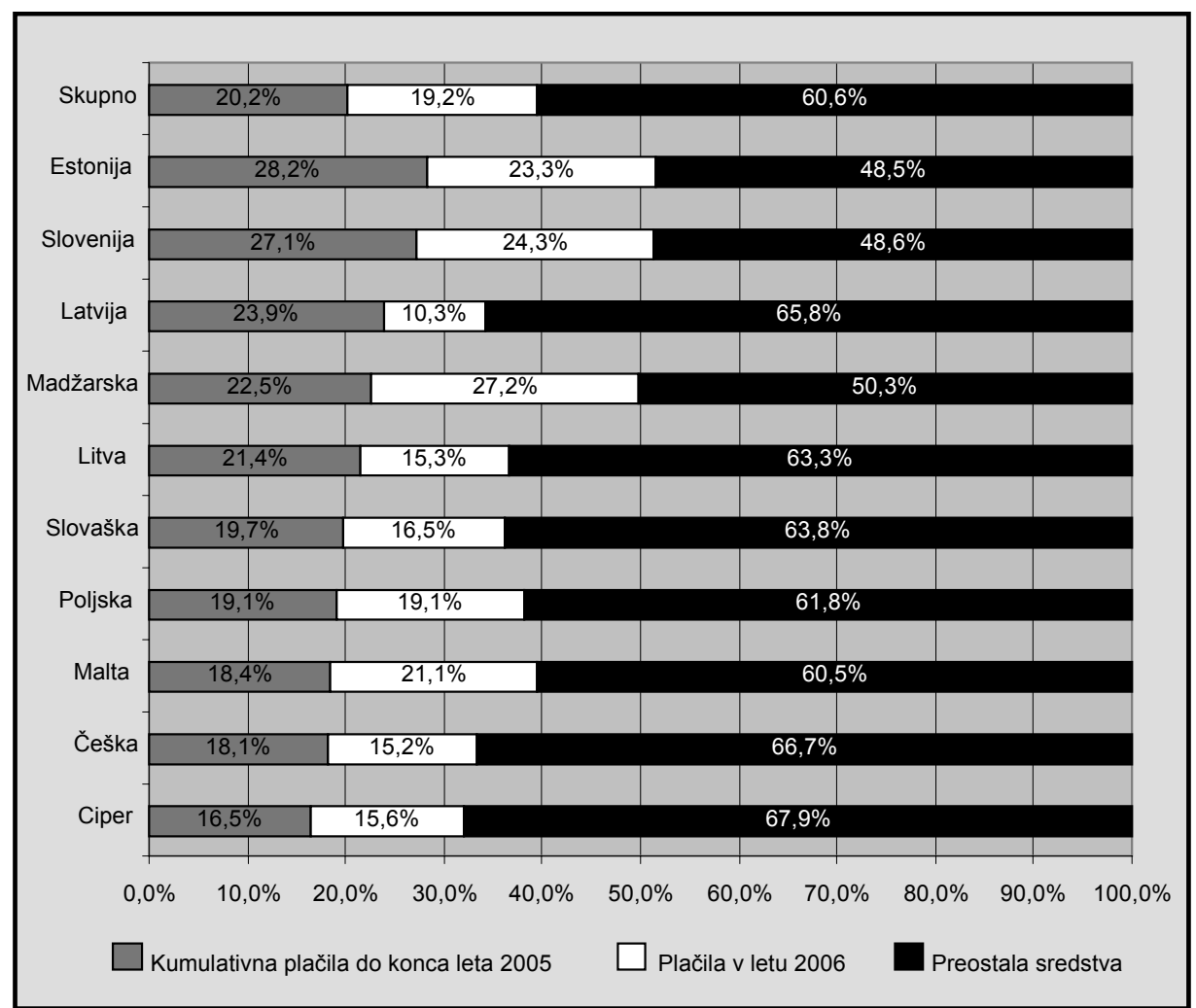

Vir: Analysis of the budgetary implementation of the Structural Funds, 2007.

Ugotovimo lahko, da sta v prvem obdobju članstva Estonija in Slovenija v relativnem smislu najuspešnejši državi pri izkoriščanju obravnavanih sredstev EU, saj sta izkoristili dobrih 51 odstotkov razpoložljivih sredstev. Tesno jima po uspešnosti sledi Madžarska s slabimi 50 odstotki. Na drugi strani so države, kot sta Ciper in Češka z relativno najnižjo stopnjo (32,1 oziroma 33,3 odstotki) uspešnosti črpanja razpoložljivih EU sredstev. Predvsem zaradi slednjih je skupna uspešnost črpanja novih držav članic EU relativno nizka (29,4 odstotka) in po tem kriteriju znatno zaostaja za uspešnostjo črpanja starih držav članic $\left(67,8\right.$ odstotka). ${ }^{4}$

4 Realnejšo sliko prikazuje delež plačil v prevzetih obveznostih v primerljivem obdobju s starimi državami članicami EU-15 (2000-2002). Primerjava pokaže, da so do konca leta 2006 nove države članice izkoristile 23,6 odstotka prevzetih obveznosti, medtem ko so si stare države članice v obdobju 2000-2002 izplačale 31,3 odstotka vseh prevzetih obveznosti v obdobju (Analysis of the budgetary implementation of the Structural Funds, 2007). 


\section{Aleksander Aristovnik, Neja Lah \\ Uspešnost Slovenije pri črpanju kohezijskih sredstev EU v obdobju 2004-2006}

Če upoštevamo samo leto 2006, ugotovimo, da je največji napredek dosegla Madžarska s 27,2 odstotki izkoriščenih razpoložljivih sredstev, sledita pa ji Slovenija (24,3 odstotki) in Estonija (23,3 odstotki). Najslabšo stopnjo izkoriščenosti $v$ tem letu izkazuje Latvija $z$ dobrimi 10 odstotki izkoriščenih razpoložljivih sredstev EU (glej sliko 1).

Ne glede na relativno uspešno izvajanje strukturnih skladov v letu 2006 se Slovenija zaveda, da so do konca programskega obdobja na razpolago številni izzivi in priložnosti za izboljšanje sistema izvajanja strukturnih skladov in s tem povečanja absorpcijske sposobnosti, kar pomeni dobro izhodišče za pripravo na izvajanje kohezijske politike $\vee$ novi finančni perspektivi. To je mogoče doseči predvsem s stalnimi, na izkušnjah temelječimi, poenostavitvami postopkov znotraj celotnega sistema izvajanja, z zaposlovanjem zadostnega števila strokovno usposobljenega kadra, s poenostavitvami domače zakonodaje (npr. sveže sprejeti Zakon o javnih naročilih (Ur. I. RS, št. 128/2006)), kar bi vodilo k uresničitvi cilja, da Slovenija do konca leta 2008 porabi tudi vsa dodeljena sredstva v programskem obdobju 2004-2006 (Letno poročilo 2006 o izvajanju EPD $\checkmark$ programskem obdobju 2004-2006, 2007, str. 7).

\section{Sistem črpanja kohezijskih sredstev EU v Sloveniji}

Za upravljanje sredstev kohezijske politike EU so zadolženi pristojni organi držav članic oziroma njihovih regij, pri čemer poteka upravljanje v partnerstvu z Evropsko komisijo (EK), regionalnimi, lokalnimi in drugimi pristojnimi javnimi oblastmi, gospodarskimi in socialnimi partnerji ter z vsemi drugimi ustreznimi pristojnimi organi. Partnerstvo je načelo $v$ vseh fazah upravljanja od priprave financiranja do spremljanja in vrednotenja pomoči. EK ne predpisuje natančno, kako morajo države članice organizirati izvajanje strukturnih skladov. EK le okvirno predpiše funkcije in imena pomembnejših udeležencev. Organe, ki sodelujejo pri izvajanju strukturnih skladov, predpisujeta Uredba Sveta (ES) št. 1260/1999 z dne 21. junija 1999 o splošnih določbah o strukturnih skladih ter izvedbena Uredba Komisije (ES) št. 438/2001. Organe, ki sodelujejo pri izvajanju Kohezijskega sklada (KS) pa predpisujeta Uredba Sveta (ES) št. 1164/1994 z dne 16. maja 1994 o ustanovitvi Kohezijskega sklada ter izvedbena Uredba Komisije (ES) št. 
Aleksander Aristovnik, Neja Lah

Uspešnost Slovenije pri črpanju kohezijskih

sredstev EU v obdobju 2004-2006

1386/2002. Ključna organa za upravljanje sredstev kohezijske politike EU sta organ upravljanja in plačilni organ, ki ju določi država članica.

Organ upravljanja za vse sklade je Služba vlade Republike Slovenije za lokalno samoupravo in regionalno politiko (SVLR) oziroma njena notranja organizacijska enota, Urad za kohezijsko politiko EU. Ustanovljen je bil s Sklepom Vlade RS decembra 2002 (Ur. I. RS, št. 115/02) in je odgovoren za koordinacijo priprave EPD, za pogajanja z EK, za upravljanje EPD in učinkovito ter pravilno črpanje sredstev iz strukturnih skladov in KS. V Sloveniji obstaja samo en organ upravljanja sredstev strukturnih skladov in KS.

\section{Slika 2: Struktura izvajanja strukturnih skladov}

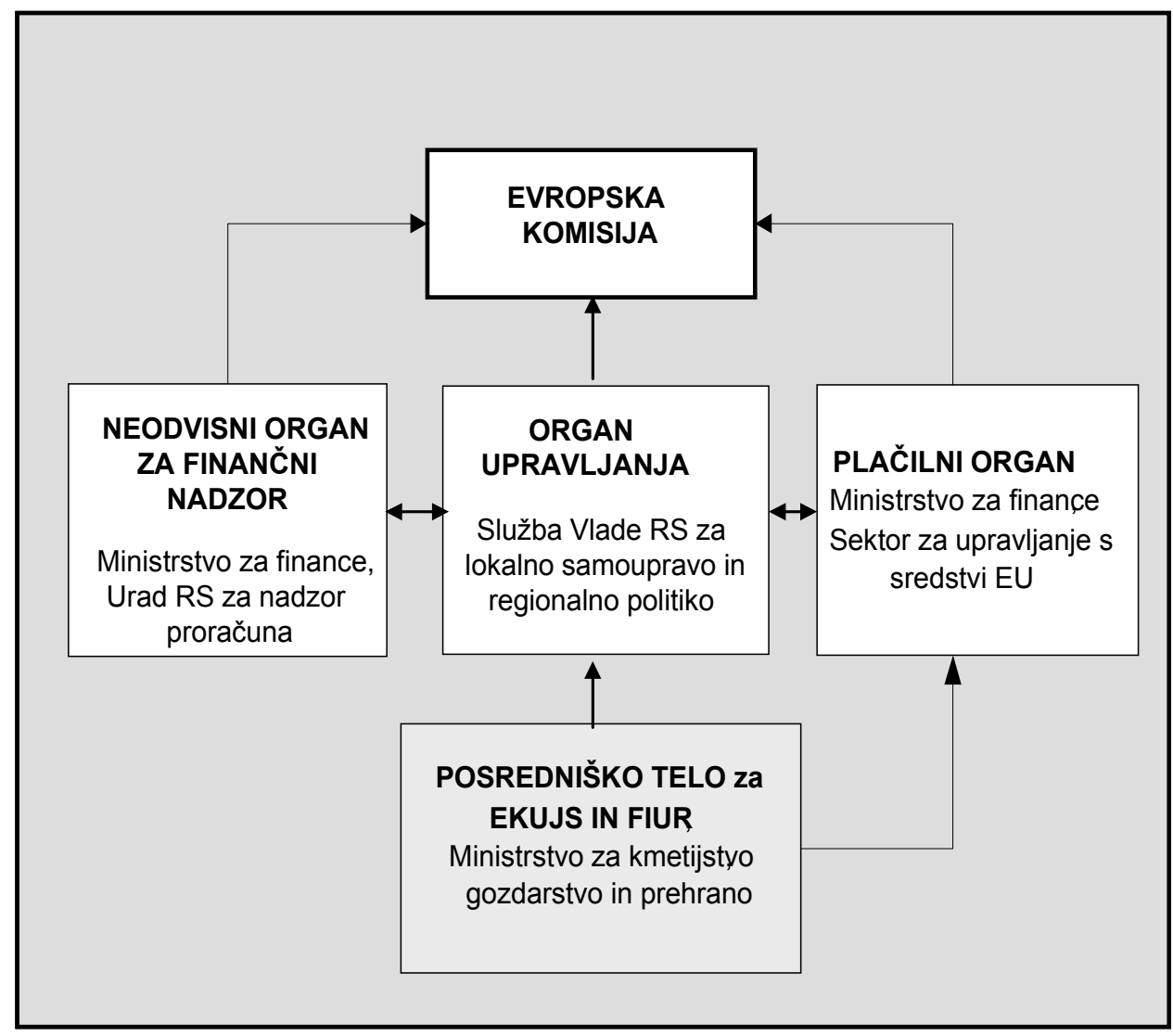

Vir: Opis sistema upravljanja in nadzora za strukturne sklade, SVLR. 2006. str. 6.

Plačilni organ je notranja organizacijska enota Ministrstva za finance (MF), Sektor donacij EU - nacionalni sklad. Plačilni organ deluje kot osrednji organ za 


\section{Aleksander Aristovnik, Neja Lah \\ Uspešnost Slovenije pri črpanju kohezijskih sredstev EU v obdobju 2004-2006}

finančno poslovodenje strukturnih skladov in KS in z njimi povezanih finančnih tokov $\vee$ okviru odgovornosti državnega sekretarja na MF, pristojnega za proračun. Plačilni organ je odgovoren predvsem za izvrševanje povračil iz sredstev strukturnih skladov EU $\vee$ proračun na podlagi odobrenih zahtevkov za povračilo, ki jih prejme od končnih upravičencev oziroma posredniških teles. $V$ Sloveniji obstaja samo en plačilni organ, pristojen za vsa sredstva strukturnih skladov in KS. Neodvisni organ za finančni nadzor je Urad Republike Slovenije za nadzor proračuna, ki je organ $v$ sestavi MF, in opravlja naloge neodvisnega nadzora vseh skladov EU (glej sliko 2).

Posredniško telo je, kot že omenjeno, odgovorno za izvedbo posamezne prednostne naloge EPD. Posredniška telesa so bila do 1. marca 2006 notranje organizacijske enote: Ministrstvo za gospodarstvo (MG) za Evropski sklad za regionalni razvoj (ESRR), Ministrstvo za delo, družino in socialne zadeve (MDDSZ) za Evropski socialni sklad (ESS), Ministrstvo za kmetijstvo, gozdarstvo in prehrano (MKGP) za Usmerjevalni oddelek Evropskega kmetijskega usmerjevalnega in jamstvenega sklada (EKUJS) in Finančni instrument za usmerjanje ribištva (FIUR). S 1. marcem 2006 sta se posredniški telesi za ESRR in ESS, to sta MG in MDDSZ, zaradi poenostavitve postopkov prenesli na organ upravljanja, na SVLR. Ostalo je posredniško telo za EKUJS in FIUR, ki je še vedno MKGP. $V$ okviru ESRR imamo 5 nosilcev proračunske postavke: MG, Ministrstvo za šolstvo in šport (MŠŠ), Ministrstvo za visoko šolstvo znanost in tehnologijo (MVZT), Ministrstvo za kulturo (MK) in Ministrstvo za promet $(\mathrm{MzP}), v$ okviru ESS imamo 3 nosilce proračunske postavke, to so: MDDSZ, Mšš in MVZT. V okviru tretje prednostne naloge pa se $\vee$ vseh ukrepih kot nosilec proračunske postavke pojavlja MKGP.

V okviru KS se pojavljata dve posredniški telesi, to sta: MzP za področje prometa in Ministrstvo za okolje in prostor (MOP) za področje okolja (glej sliko 3). $V$ primeru KS nimamo nosilcev proračunske postavke, za posredniškimi telesi se pri izvajanju pojavljajo izvajalska telesa, za promet Družba za avtoceste Republike Slovenije (DARS) in Agencija za železniški promet (AŽP), za okolje pa so to občine. 
Aleksander Aristovnik, Neja Lah

Uspešnost Slovenije pri črpanju kohezijskih

sredstev EU v obdobju 2004-2006

Slika 3: Struktura izvajanja Kohezijskega sklada

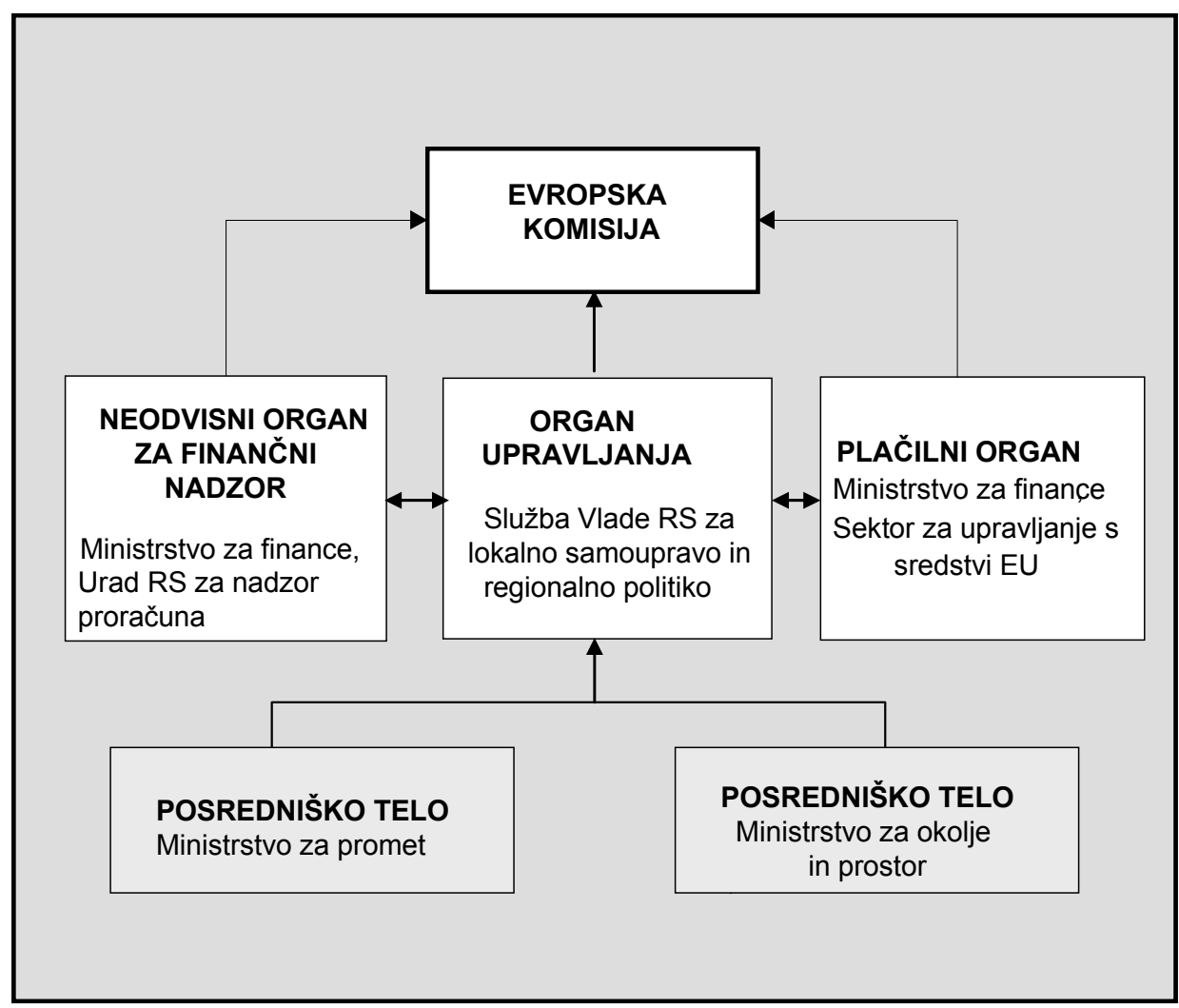

Vir: Lastna slika.

\section{Problemi pri črpanju kohezijskih sredstev EU}

Po začetku izvajanja EPD v letu 2004 se je Slovenija, enako kot druge države članice, soočila z nekaterimi uvajalnimi težavami pri izvedbi. Delovanje sistema kohezijske politike je namreč precej kompleksno, kar neizogibno zahteva določeno obdobje učenja za normalno uveljavitev vseh pravil in postopkov. Ne glede na to, opravljene analize kažejo, da je bila splošna strateška usmerjenost EPD prava, kar velja tako na ravni ministrstev kot tudi odziv na terenu, kjer je absorpcijska sposobnost visoko presegala razpoložljiva sredstva. Na negativni strani vendarle velja izpostaviti opozorilo neodvisnega vrednotenja, da je zaradi sektorskega načina načrtovanja prišlo do načrtovanja 


\section{Aleksander Aristovnik, Neja Lah \\ Uspešnost Slovenije pri črpanju kohezijskih sredstev EU v obdobju 2004-2006}

na podlagi problemskega drevesa in je bilo na tej osnovi posvečene preveč pozornosti problemom in premalo priložnostim. Navedeno naj bi bilo še posebej opazno na ravni instrumentov, kjer ni $v$ zadostni meri prišlo do povezovanja med ukrepi in do povezovanja teh inštrumentov na projektni ravni. Tej dimenziji, to je zagotavljanju sinergij ter usmerjenosti na izkoriščanje priložnosti, bo treba $\vee$ izvedbeni strukturi dati dodatno težo. To bo možno doseči tako z bolj kvalitetnim načrtovanjem, aktivnejšo vsebinsko vlogo organa upravljanja ter večjo vključenostjo zunanjih neodvisnih strokovnjakov $v$ pripravo, spremljanje in vrednotenje izvajanja instrumentov (Državni razvojni program 2007-2013, 2006, str. 43).

S stališča vsebinskih izkušenj pri izvajanju EPD velja posebej izpostaviti naslednje ugotovitve. Pri izvajanju nekaterih instrumentov je bilo $v$ prvi fazi opaziti prezahtevno razpisno dokumentacijo, kar je bilo kasneje izboljšano, je pa povzročilo precej stroškov in nejevolje prijaviteljev. Prav tako je bila vsebina nekaterih instrumentov zelo ambiciozna (npr. pri inovacijskem okolju), kar pa se je glede na strateške cilje vendarle izkazalo kot ustrezna usmeritev, ki so ji bili prijavitelji kos. $\vee$ okviru ESS je bilo pri nekaterih ukrepih opaziti precej razdrobljeno strukturo instrumentov, kjer obstaja nekaj pomislekov glede doseganja kritične mase za doseganje vplivov in preglednosti. Glede učinkovitosti je neodvisno vrednotenje $\vee$ pozitivnem smislu posebej izpostavilo programe usposabljanja neaktivnih na delovnem mestu, usposabljanje zaposlenih ter, še posebej z vidika potrebnosti, prilagajanje šolskih programov potrebam gospodarstva. V okviru EKUJS in FIUR je bilo glede na razpoložljiva sredstva in zastavljene cilje treba vztrajati pri sofinanciranju točno določenih aktivnosti. Pri tem se je do neke mere izkazalo, da so bile določbe $v$ EPD prepodrobne, kar je preprečevalo učinkovito prilagajanje instrumentov potrebam, skladno s pridobljenimi izkušnjami. Prav tako je bilo opaziti nekaj težav pri zagotavljanju lastnega sofinanciranja in sicer še posebej pri ribiških ukrepih.

\subsection{Administrativna usposobljenost}

Nepogrešljivi element v izvajanju kohezijske politike EU predstavlja administrativna usposobljenost. Že $\vee$ začetnih mesecih črpanja skladov EU se je izkazalo, da institucije ne razpolagajo z zadostnim številom kadrov. Zato so morale vse institucije, vključene v izvajanje strukturnih skladov in Kohezijskega sklada, pripraviti analizo administrativne usposobljenosti, ki naj bi po posameznih 
Aleksander Aristovnik, Neja Lah

\section{Uspešnost Slovenije pri črpanju kohezijskih}

sredstev EU v obdobju 2004-2006

resorjih prikazala manjkajoče število zaposlenih ter ocenila potrebo po nadaljnjih zaposlitvah.

Vlada RS je tako na 64. redni seji, dne 4. marca 2004 obravnavala dokument "Informacija o poteku aktivnosti za črpanje sredstev strukturnih instrumentov $v$ okviru Enotnega programskega dokumenta in Referenčnega okvira za Kohezijski sklad", v katerem je bilo podano predhodno poročilo o stanju administrativne usposobljenosti na področju strukturnih skladov in KS. Prikazana je bila dinamika zaposlovanja posameznih institucij, vključenih $v$ implementacijo strukturnih skladov in KS, v obdobju 2004-2005 in sicer za stanje na dan 3.12.2004, ko je potekel rok za posredovanje gradiva SVLR. Zaradi pomembnosti nadzornih funkcij pri črpanju skladov EU so bili ločeno prikazani tudi podatki o številu zaposlenih, ki izvajajo kontrole po 4. členu Uredbe Komisije (ES), o številu zaposlenih v notranje revizijskih službah posameznih institucij, ki izvajajo revizijo skladov EU, ter zaposlenih po institucijah, ki so financirani iz tehnične pomoči v okviru EPD RS. Ugotovljeno je bilo, da so ministrstva $v$ letu 2004 realizirala le $26,85^{\mathbf{5}}$ novih zaposlitev od skupno 41 namensko odobrenih zaposlitev za leto $2004-2005$.

SVLR je konec leta 2006 ponovno izvedla analizo o stanju in potrebah na področju administrativne usposobljenosti udeležencev pri porabi sredstev strukturne politike in KS v RS. Skupaj je bilo zaposlenih na področju kohezijske politike 257 javnih uslužbencev, ker pa vsi dela na področju skladov ne opravljajo 100\%, je bilo neto, torej $\vee$ ekvivalentu polnega delovnega časa, zaposlenih 163 javnih uslužbencev. Povprečna delovna doba javnih uslužbencev je od 7,5 let do 19 let, povprečje pa je 12,5 leta. S skladi se torej ukvarjajo tako povsem na novo zaposleni z delovno dobo nekaj mesecev, kot tudi starejši z delovno dobo nad 20 let. Ta podatek je tudi neposredno povezan z oceno največjih kadrovskih težav, ki prav slednje - premalo delovnih izkušenj - omenja kot drugo največjo težavo (takoj za prevelikim obsegom dela oziroma preobremenjenostjo). Po opravljeni analizi administrativne usposobljenosti so bili definirani naslednji problemi: prevelik obseg dela oziroma preobremenjenost; premalo delovnih izkušenj in premalo usposabljanja ali izobraževanja; premalo zaposlenih.

5 Podatek ni podan $v$ celi številki, ker posamezni zaposleni izvajajo le del svojih nalog na področju EU skladov. 


\section{Aleksander Aristovnik, Neja Lah \\ Uspešnost Slovenije pri črpanju kohezijskih sredstev EU v obdobju 2004-2006}

Poleg teh najpogostejših težav so udeleženci, vključeni v strukturne in KS, izpostavili še slabo vzdušje med zaposlenimi, slabo nagrajevanje in slabo vrednotenje dela, prenizke plače, delo za določen čas, ob tem pa so nekateri navedli še slabo koordinacijo vpletenih, razpršenost kadrov, prenizko motivacijo ter preveč administracije.

Ključna ukrepa za izboljšanje administrativne usposobljenosti sta:

- dodatne zaposlitve,

- dodatno usposabljanje doma in $v$ tujini.

Primerjava števila zaposlenih, ki jo je SVLR izvedel z drugimi novimi državami članicami, kaže, da v Sloveniji uslužbenec $v$ povprečju letno upravlja z več sredstvi kot je to primer npr. $\vee$ Latviji, Poljski ali Madžarski. V Sloveniji posameznik v povprečju upravlja s 915 tisoč evri letno (cene 2004), medtem ko so primerljive številke za ostale tri države 381,837 ter 806 tisoč evrov letno. Navedeno lahko pomeni, da je slovenski sistem izvedbe bolj učinkovit oziroma, da je bolj obremenjen kot $v$ drugih državah članicah. Za potrebe nove finančne perspektive bo treba zaradi precejšnjega števila novih potrebnih kadrov ter tudi vključitve institucij, ki do sedaj niso sodelovale pri izvajanju, izobraževanje organizirati tako, da se na praktičen način predstavi delovanje sistema.

\subsection{Drugi problemi}

Med drugimi problemi, ki so se še pokazali pri implementaciji, lahko izpostavimo:

- zapletena razpisna dokumentacija (predviden čas izvedbe javnih razpisov je bil vedno daljši od načrtovanega, prevelika kompleksnost, nejasen predmet javnega razpisa, nejasni pogoji za sodelovanje, slabo določena ciljna skupina),

- slaba pripravljenost prijaviteljev (predvsem v primeru EKUJS, kjer je šlo po večini za prijavljanje kmetov na javne razpise),

- pomanjkanje sinergij med različnimi ukrepi in skladi (npr. povezovanje med pridelavo, trženjem in trgom),

- izvajanje kontrol po 4. členu Uredbe Komisije (ES) - zaradi pomanjkanja izkušenega kadra so se težave pokazale na vseh področjih preverjanja (težko preverljiva resničnost dobave blaga, sofinanciranih proizvodov in storitev, resničnost izdatkov; neskladnost projekta oz. programa s pro- 
Aleksander Aristovnik, Neja Lah

Uspešnost Slovenije pri črpanju kohezijskih

sredstev EU v obdobju 2004-2006

gramskimi dokumenti, težko preverljiva sočasnost prispevka iz več kot enega sklada; nepoznavanje postopkov oddaje javnih naročil in drugih postopkov za dodeljevanje subvencij (državnih pomoči) ali sofinanciranje projektov; neupoštevanje pravil informiranja in obveščanja javnosti, okoljevarstvenih pravil in zagotavljanja enakih možnosti),

- izvajanje kontrol po 9. členu Uredbe Komisije (ES) št. 438/2001, kjer gre za vzpostavitev izvajanja administrativnih in kontrol na kraju samem, ki jih mora po tej uredbi izvajati plačilni organ.

- izvajanje nadzora po 10. členu Uredbe Komisije (ES) št. 438/2001 je pokazalo naslednje težave: nezadostna kadrovska struktura v posameznih institucijah in nezadostna usposobljenost kadra, manjkajoči podrobni opisi postopkov, nepravočasno in pomanjkljivo delovanje kontrol po 4. členu Uredbe Komisije (ES) št. 438/2001 in Uredbe Komisije (ES) št. 1386/2002, nedelovanje nujno potrebnega informacijskega sistema za spremljanje in kontrolo aktivnosti, predvsem za področje ESS.

\section{Pogled v prihodnost}

V obdobju tekoče finančne perspektive (2007-2013) si je Slovenija kot enotna regija (na ravni NUTS 2) zagotovila približno 4,5 milijarde evrov sredstev EU oz. na letni ravni skorajda štirikratno povečanje kohezijske pomoči, kar daje Sloveniji zgodovinsko priložnost, da tudi s temi sredstvi v skladu z zastavljenim ciljem v Strategiji razvoja Slovenije (2005) dohiti povprečje EU do leta 2013. V sedemletnem obdobju naj bi tako slovenski proračun od EU prejel do okoli 2 milijardi evrov več sredstev, kot naj bi jih prispeval. Takšen neto položaj nadgrajuje to, kar je bilo izpogajano $v$ času pristopnih pogajanj in pomeni več kot dvakrat boljši neto položaj od tistega, ki ga je Slovenija imela v letih 2004-2006. ${ }^{6}$ Sprememba pravil črpanja, predvsem podaljšanje obdobja črpanja ${ }^{7}$ in višja

6 Po vladnih ocenah naj bi Slovenija $v$ obdobju 2007-2011 pridobila v povprečju 0,43 odstotka BDP neto priliva letno, kar je več kot dvakrat toliko kot je prejela v letu 2006.

7 Države članice so se $v$ pogajanjih dogovorile o uvedbi pravila $\mathrm{N}+3$ tako za strukturne sklade kot tudi za Kohezijski sklad do leta 2010, in sicer bo ta za vse države pod 85 odstotki BDP na prebivalca EU (podatki za obdobje 2001-2003) znašala 85 odstotka. $V$ to skupino poleg novink (EU-12) spadajo še Grčija in Portugalska (Cohesion Policy regulations and the Community Strategic Guidelines: relevant provisions for the environment, 2006, str. 7-8). 


\section{Aleksander Aristovnik, Neja Lah \\ Uspešnost Slovenije pri črpanju kohezijskih sredstev EU v obdobju 2004-2006}

stopnja sofinanciranja ${ }^{\boldsymbol{s}_{\text {s }}}$ sta z vidika proračuna Slovenije in priprave primernih projektov ter zagotovitve drugih pogojev za črpanje sredstev iz proračuna EU dobrodošli dodatni spodbudi k temu, da Slovenija razpoložljiva sredstva tudi učinkovito in uspešno porabi.

Z uspehom pri pogajanjih o novi finančni perspektivi pa je Slovenija izpolnila le potreben pogoj, da $v$ skladu s svojimi razvojnimi prioritetami čim bolje izkoristi razpoložljiva sredstva EU. Kot zadosten pogoj uspešnega črpanja sredstev iz proračuna EU se pogosto omenja več predpogojev, ki se nanašajo na absorpcijsko sposobnost države. Tako Mrak in Wostner (2005) izpostavljata predvsem štiri domače predpogoje. Prvi predpogoj zajema t. i. realno absorpcijsko sposobnost, ki vključuje realne potrebe države in razpoložljivost proizvodnih dejavnikov. Drugi se nanaša na t. i. finančno absorpcijsko sposobnost, ki vključuje sposobnost zagotavljanja domačega sofinanciranja. Tretji predpogoj pomeni zagotovitev t. i. programsko projektne absorpcijske sposobnosti, ki se nanaša na pravočasno in kakovostno pripravo programskih dokumentov. Zadnji predpogoj pa zajema t. i. administrativno absorpcijsko sposobnost, ki $\vee$ prvi vrsti zagotavlja izpeljavo kompleksnih postopkov na državni ravni kot tudi na ravni prijavitelja projekta.

Kar zadeva realne sposobnosti, Slovenija ne pričakuje večjih težav, sploh ker bo do leta 2013 predvidoma soočena z izjemno velikimi investicijskimi projekti (glej npr. Resolucijo o nacionalnih razvojnih projektih za obdobje 20072023). ${ }^{9}$ Tudi z vidika finančne absorpcijske sposobnosti Slovenija $v$ tekoči finančni perspektivi ne pričakuje večjih omejitev. To velja predvsem za državno raven, medtem ko je na ravni občin in podjetij za pričakovati določene likvidnostne omejitve. $\vee$ vsakem primeru je tekoče obdobje zaradi znatnega, več milijardnega obsega razpoložljivih sredstev EU za Slovenijo finančno veliko bolj zahtevno kot predhodno obdobje 2004-2006. Bolj vprašljivo je izpolnjevanje programsko projektne absorpcijske sposobnosti, kjer je problematična predvsem priprava ustrezne strategije in programskih osnov glede na realne potrebe države, ustreznost konkretnih izvedbenih instrumentov in pripravljenost ustrezne projektne dokumentacije. Medtem ko so nacionalni strateški dokumenti (Državni

$8 \mathrm{~V}$ kompromisnem dogovoru o tekoči finančni perspektivi 2007-2013 je državam uspelo doseči višjo stopnjo sofinanciranja, in sicer ponovno samo za tiste države, ki v obdobju 20012003 ne dosegajo 85\% BDP na prebivalca, in to tako za strukturne sklade kot tudi za Kohezijski sklad.

$9 \mathrm{Na}$ tej osnovi bo lahko Slovenija brez težav absorbirala do $4 \%$ svojega BDP sredstev EU (kolikor je postavljena zgornja meja s strani EU). 


\section{Aleksander Aristovnik, Neja Lah \\ Uspešnost Slovenije pri črpanju kohezijskih sredstev EU v obdobju 2004-2006}

razvojni program (DRP) 2007-2013, Strategija razvoja Slovenije (SRS) in Nacionalni strateški referenčni okvir (NSRO) 2007-2013 relativno dobro pripravljeni, pa se pomanjkljivosti kažejo $v$ prevelikem neskladju med nacionalnim programskim okvirom in kasnejšo realizacijo konkretnih investicijskih projektov (izvedenih $\vee$ okviru operativnih programov) ${ }^{\mathbf{1 0}}$. V obdobju 2004-2006 je bilo tako opaziti zapleteno in zahtevno razpisno dokumentacijo, kar je pri prijaviteljih povzročalo precej stroškov in nejevolje. $V$ tekoči finančni perspektivi bo treba $\vee$ fazi priprave instrumentov posvetiti več pozornosti kakovosti razpisne dokumentacije, $v$ okviru katere bo treba tudi pri kompleksnih projektnih strukturah zagotoviti pregleden in enostaven odnos med prejemniki in dodeljevalci spodbud." Izkušnje pri izvajanju prav tako kažejo, da je bolj smiselno združevati dejavnosti glede na vsebinske cilje, ne pa glede na tip investicije oz. sofinanciranja (državne pomoči - javne investicije) (NSRO, 2007, str. 51).

Zagotovo bo za Slovenijo $v$ prihodnosti največja ovira za uspešnejše črpanju sredstev EU administrativna (ne)sposobnost državne administracije. Za Slovenijo kot majhno državo je primerno, da ima centraliziran sistem črpanja z enim organom upravljanja (tj. SVLR) in enim plačilnim organom (tj. MF). S centraliziranim načinom upravljanja strukturnih skladov je lažje spremljati učinke kohezijske politike, hkrati pa se hitreje zazna (ne)sposobnost črpanja EU sredstev na ravni programov po ministrstvih ter se na ta način omogoča prerazporeditev sredstev tja, kjer je črpanje uspešnejše in pospešeno. Nenazadnje takšen način črpanja sredstev EU tudi zmanjšuje podvajanje izvedbenih struktur in posledično omejuje zaposlovanje $v$ državni upravi (Okvir gospodarskih in socialnih reform za povečanje blaginje $\vee$ Sloveniji, 2005, str. 104). Administrativno usposobljenost črpanja sredstev EU bo mogoče izboljšati tudi z uvedbo trajnega izobraževanja tako zaposlenih $\vee$ državni upravi kot tudi prijaviteljev projektov (podjetij, neprofitnih organizacij itn.), kjer se bodo zaposleni spoznavali s sistemi načrtovanja, priprave projektov in njihove izvedbe.

10 Operativni programi s skladnim nizom razvojnih prioritet določajo razvojno strategijo in cilje razvoja, ki jih želi država na posameznem področju doseči s finančno pomočjo evropskih skladov. Imeli naj bi enako funkcijo kot Enotni programski dokument za obdobje 2004-2006 in so torej pravna podlaga za črpanje sredstev, saj jih Evropska komisija potrdi z odločbo.

11 Medtem ko je programska osnova na nacionalni ravni zadovoljiva, pa se pomanjkljivosti kažejo na regionalni in lokalni ravni, kjer ukrepi velikokrat niso skladni z dejanskim stanjem in potrebami. Tudi zato bo $v$ prihodnosti treba pri pripravi projektne dokumentacije zagotoviti večjo vlogo regionalni oz. lokalni ravni. 


\section{Aleksander Aristovnik, Neja Lah \\ Uspešnost Slovenije pri črpanju kohezijskih sredstev EU v obdobju 2004-2006}

\section{Sklep}

Slovenija je bila $v$ obdobju 2004-2006 relativno uspešna porabnica razpoložljivih sredstev EU. $\vee$ tem obdobju je prejela skoraj 200 milijonov evrov iz proračuna EU in si pridobila vrsto izkušenj za uspešno črpanje sredstev v tekoči finančni perspektivi 2007-2013, ki Sloveniji ponuja približno 4,5 milijarde evrov (od tega približno 3,7 milijarde evrov za kohezijsko politiko). Ta evropska sredstva, $\vee$ primerjavi s stanjem $\vee$ obdobju 2004-2006, pomenijo na letni ravni skorajda štirikratno povečanje pomoči, ki bo namenjena razvoju regij, podjetništvu, inovativnosti, človeškim virom, prometu in okolju. Sprememba pravil črpanja, predvsem podaljšanje obdobja črpanja in višja stopnja sofinanciranja (do 85 odstotkov celotne vrednosti projekta) z vidika proračuna Republike Slovenije in priprave primernih projektov ter zagotovitve drugih pogojev za črpanje sredstev iz proračuna EU, spodbujata optimistična pričakovanja, da bo država pridobila čim večji delež razpoložljivih EU sredstev.

Čeprav je bila Slovenija v prvem obdobju članstva ena najuspešnejših porabnic evropskih sredstev med novimi državami članicami, pa je do konca leta 2006 izkoristila le okoli polovice dodeljenih sredstev. Glavni razlog za to lahko iščemo predvsem $v$ slabi izkoriščenosti kohezijskih in schengenskih sredstev ter neugodni dinamiki prejemkov iz proračuna EU. Tudi zaradi tega je Slovenija izvedla številne aktivnosti, ki naj bi izboljšale uspešnost črpanja kohezijskih sredstev EU, in sicer:

- prenos funkcij posredniških teles za ESRR in ESS na SVLR-organ upravljanja; na ta način je bila odpravljena ena raven koordinacije, kar je prispevalo $k$ večji odzivnosti, preglednosti in učinkovitosti celotnega sistema;

- okrepljeno sodelovanje in komunikacija med organom upravljanja, plačilnim organom, Uradom RS za nadzor proračuna in resornimi ministrstvi (tedenski operativni sestanki predstavnikov vseh navedenih institucij; tedenski sestanki pristojnih ministrov);

- sprejetje finančnih ukrepov za optimizacijo črpanja sredstev s prerazporeditvami in dodelitvijo dodatnih pravic porabe;

- redno spremljanje izvajanja in poročanje pristojnim institucijam (ministrom, predsedniku vlade, Državnemu zboru, Evropski komisiji, Mednarodnemu denarnemu skladu...); 


\section{Aleksander Aristovnik, Neja Lah \\ Uspešnost Slovenije pri črpanju kohezijskih sredstev EU v obdobju 2004-2006}

- $\quad$ zaveza ministrstev, da dosledno uporabljajo finančna zavarovanja za resnost izvedbe del pri pogodbah, saj so upravičenci naknadno odstopali od pogodb;

- boljša promocija in informiranje o strukturnih skladih in KS;

- dodatno zaposlovanje na področju kontrol upravičenosti stroškov iz sredstev tehnične pomoči;

- boljša priprava instrumentov;

- $\quad$ priprava preglednih in jasnejših navodil ter usmeritev;

- $\quad$ natančnejša opredelitev upravičenih stroškov.

Slovenija bo v tekočem finančnem obdobju (2007-2013) še bolj centralizirala sistem upravljanja in nadzora ter nekoliko povečala vpliv organa upravljanja, ki bo imel večjo vlogo pri potrjevanju instrumentov oz. operacij, pri finančnem upravljanju, pri prerazporeditvi sredstev med projekti in/ali ministrstvi in pri kontroli porabe sredstev EU. Če želi Slovenija izkoristiti znatna razpoložljiva sredstva EU $\vee$ tekoči finančni perspektivi, bo torej morala $\vee$ prihodnosti nujno povečati administrativno sposobnost, tj. realno, finančno, programsko projektno in predvsem administrativno sposobnost. Za uspešnejše črpanje evropskih sredstev bo tako, poleg dodatnega prestrukturiranja proračunskih izdatkov in uporabe dobrih praks iz tujine, treba zagotoviti tudi višjo stopnjo strokovnosti in učinkovitosti oz. uspešnosti slovenske državne uprave.

Aleksander Aristovnik je doktor ekonomskih znanosti, zaposlen na Fakulteti za upravo Univerze $\checkmark$ Ljubljani kot docent za področje ekonomike javnega sektorja. Prav tako je docent za področje mednarodne ekonomije na Ekonomski fakulteti Univerze $v$ Ljubljani. Je avtor oz. soavtor številnih domačih in tujih člankov ter delov monografij. V svojem raziskovalnem delu se ukvarja predvsem s področjem mednarodne ekonomije, javnih financ in procesov evropskega integriranja.

Neja Lah je univerzitetna diplomirana ekonomistka, zaposlena na Službi Vlade RS za lokalno samoupravo in regionalno politiko, $v$ Uradu za evropsko kohezijsko politiko, natančneje $v$ Sektorju za sisteme in nadzor. Njeno področje delovanja zajema predvsem spremljanje sistema upravljanja in nadzora vseh štirih strukturnih skladov in Kohezijskega sklada. Odgovorna je tudi za področje morebitnih nepravilnosti $v$ implementacijskih strukturi evropskih skladov ter za področje spremljanja revizijskih misij domačih in tujih institucij. 


\section{Aleksander Aristovnik, Neja Lah \\ Uspešnost Slovenije pri črpanju kohezijskih sredstev EU v obdobju 2004-2006}

\section{Literatura in viri}

- Analysis of the budgetary implementation of the Structural Funds in 2006. (http://ec.europa.eu/budget/library/documents/revenue_expenditure/expenditur e/sf_imple_rep_2006_en.pdf - 5. junij 2007)

- Bilten javnih finance. Ljubljana: Ministrstvo za finance. Različne številke.

- Cohesion Policy regulations and the Community Strategic Guidelines: relevant provisions for the environment. Brussels: European Commission, 2006. 15 str.

- Državni razvojni program Republike Slovenije za obdobje 2007-2013. Ljubljana: Služba Vlade RS za lokalno samoupravo in regionalno politiko, 2006. 96 str.

- Enotni programski dokument 2004-2006. Ljubljana: Služba vlade RS za strukturno politiko in regionalni razvoj, 2004. 235 str.

- EU skladi: Spletna stran Službe Vlade RS za lokalno samoupravo in regionalno politiko. http://www.sigov.si/euskladi/skladi/strukt.html, 23.5.2007.

- Letno poročilo 2006 o izvajanju Enotnega programskega dokumenta Republike Slovenije za programsko obdobje 2004-2006. Ljubljana: Služba Vlade RS za lokalno samoupravo in regionalno politiko, 2007. $166 \mathrm{str}$.

- Mrak, M. in Wostner, P. (2005): Absorpcijska sposobnost Republike Slovenije za črpanje sredstev EU. Ljubljana. IB revija, 3/2005, 39, str. 4-21.

- Nacionalni strateški referenčni okvir 2007-2013. Ljubljana: Služba Vlade RS za lokalno samoupravo in regionalno politiko, 2007. $121 \mathrm{str}$.

- Okvir gospodarskih in socialnih reform za povečanje blaginje $\vee$ Sloveniji. Ljubljana: Služba Vlade RS za razvoj, 2006. 136 str.

- $\quad$ Opis sistema upravljanja in nadzora za strukturne sklade (v okviru Enotnega programskega dokumenta Rebublike Slovenije za programsko obdobje 2004 2006) v Republiki Sloveniji. Služba Vlade RS za lokalno samoupravo in regionalno politiko, 2006. 107 str.

- Rebalans proračuna RS za leto 2005. Ljubljana: Ministrstvo za finance (http://www.sigov.si/mf/slov/proracun/sprejet_proracun/2005/rebalans/rebalans _2005.htm - 8. julij 2007)

- Resolucija o nacionalnih razvojnih projektih za obdobje 2007 - 2023. Ljubljana: Služba Vlade Republike Slovenije za razvoj, 2006. 75 str.

- $\quad$ Spremembe proračuna RS za leto 2004. Ljubljana: Ministrstvo za finance (http://mww.sigov.si/mf/slov/proracun/sprejet_proracun/2004/spremembe_2004.htm 6. julij 2007). 
Aleksander Aristovnik, Neja Lah

\section{Uspešnost Slovenije pri črpanju kohezijskih}

sredstev EU v obdobju 2004-2006

- Uredba Komisije (ES) št. 438/2001 z dne 2. marca 2001 o določitvi podrobnih pravil za izvajanje Uredbe Sveta (ES) št. 1260/1999 glede sistemov upravljanja in nadzora pomoči, dodeljene v okviru Strukturnih skladov.

- Uredba Komisije (ES) št. 1386/2002 z dne 29. julija 2002 o določitvi podrobnih pravil za izvajanje Uredbe Sveta (ES) št. 1164/94 glede sistemov upravljanja in nadzora pomoči, dodeljene $v$ okviru Kohezijskega sklada, ter postopkov izvajanja finančnih popravkov.

- Uredba Sveta (ES) št. 1260/1999 z dne 21. junija 1999 o splošnih določbah o strukturnih skladih.

- Uredba Sveta (ES) št. 1164/1994 z dne 16. maja 1994 o ustanovitvi Kohezijskega sklada.

- Uredba o izvajanju postopkov pri porabi sredstev strukturne politike v Republiki Sloveniji (Ur. I. RS, št. 7/2006).

- Uredba o izvajanju postopkov pri porabi sredstev Kohezijskega sklada EU v Republiki Sloveniji (Ur. I. RS, št. 37/2005). 


\section{SUMMARY}

\section{THE EFFECTIVENESS OF DRAWING THE EU STRUCTURAL AND COHESION FUNDS IN SLOVENIA IN THE PERIOD 2004-2006}

EU membership offers Slovenia a unique opportunity to substantially accelerate its economic development and real convergence processes, namely activities which were not fully realised in the country's first period of membership. Although Slovenia is one of the most successful new EU funds beneficiaries, it has used only about half of the funds allocated in the 2004-2006 period. The main reason for this can be found in the weak utilisation of cohesion funds which will be the main financial inflow from the EU budget in the current financial perspective. If Slovenia wants to take advantage of the considerable amount of EU funds that is available, the country must increase its absorption (i.e. real, financial, programme project and administrative) capability. Indeed, for the more effective utilisation of EU funds further restructuring of budgetary expenditure and the deployment of good foreign practices should be accompanied with a higher level of professionalism as well as a more objective, efficient and effective state administration.

In the period of current financial perspective (2007-2013) Slovenia has, as one single region, ensured approximately EUR 4.5 billion of EU funds, or on a yearly basis, cohesion aid has increased almost four times. These funds give Slovenia a historical chance to get closer to the EU average until 2013, in accordance with the objectives set in Slovenia's Development Strategy (2005). Slovenian budget is going to receive approximately EUR 2 billion of funds more from the EU in this seven year period. This net position builds up what was negotiated in the time of accession negotiations. This net position is twice better in comparison with the one that Slovenia had in the period from 2004 to 2006. The change of absorption rules, especially extension of the absorption period and higher cofinancing rate, are from the point of view of Slovenia's budget and preparation of appropriate projects, as well as assurance of other conditions for absorption of funds from the EU budget, additional encouragements for Slovenia to spend all the available resources in an efficient and successful way. 
Aleksander Aristovnik, Neja Lah

Uspešnost Slovenije pri črpanju kohezijskih

sredstev EU v obdobju 2004-2006

With the success of negotiating the new financial perspective, Slovenia has fulfilled only the necessary condition - in accordance with its development priorities, it tries to make good use of the available EU funds as much as possible. As a sufficient condition of successful absorption of resources from the EU budget, more preconditions are mentioned and they refer to the absorption capacity of the country.

As far as the real capacities are concerned, Slovenia is not expecting any major problems, especially because it is going to be facing exceptionally big investment projects until 2013. Also, from the point of view of financial absorption capacity, Slovenia is not expecting any bigger restrictions in the current financial perspective. This is, above all, true for the national level, while certain liquidity restrictions are to be expected on the municipality and business level. In any case, this current period is, due to multi-billion volume of EU funds, for Slovenia much more demanding than the previous 2004-2006 period. Fulfilling of programme project absorption capacity is more questionable; preparation of suitable strategy is especially problematic, as well as preparation of the programme basis with regard to the needs of the country, suitability of concrete implementing instruments, and preparation of suitable project documentation. While the national strategic documents are relatively well prepared, weaknesses can be seen in a big gap between the national programme framework and later realization of concrete investment projects. In the 2004-2006 period, complex tender documentation was noticed, which caused a lot of cost and discontent on the part of the notifier. In the current financial perspective it will be essential to pay more attention to the stage of preparing instruments dedicated to the quality of tender documents, within which it will be necessary (this is also the case with complex project structures), to ensure transparent and simple relations between the recipients and line ministries. Experiences show that it is more reasonable to pool the activities regarding objective contents, and not regarding the types of investment or state aid (NSRO, 2007, 51).

The biggest obstacle in the future for Slovenia, as far as successful absorption of EU funds is concerned, is definitely administrative (in)capacity of state administration. For such a small country as Slovenia it would be suitable to have centralized system of absorption with one managing authority (GOSP) and one paying authority (Ministry of Finance). With centralized way of managing structural funds it is easier to monitor cohesion policy, and at the same time it is simpler to notice 
(in)capacity of absorption of EU funds on the level of programmes at the ministries; in this way it is also possible to transfer the funds where the absorption is more successful and accelerated. Last but not least, this kind of absorption of EU funds also reduces duplication of implementing structures, and consequently limits employment in the state administration. It will be possible to improve administrative capacity of absorption of EU funds with the implementation of permanent education in the state administration, as well as with project notifiers (firms, non-profit organisations, etc.), where the employees would get to know the system of planning, preparing projects and its implementation. 